\title{
FACTORS INCREASING THE RISK OF INACTIVITY AMONG ADMINISTRATIVE, TECHNICAL, AND MANUAL WORKERS IN WARSZAWA PUBLIC INSTITUTIONS
}

\section{ELŻBIETA BIERNAT}

\author{
Warsaw School of Economics, Warszawa, Poland \\ Collegium of World Economy, Department of Tourism
}

\begin{abstract}
Objectives: The research aims to assess the level of physical activity among administrative, technical, and manual workers employed in Warszawa public institutions and to analyze the factors that increase the risk of failing to meet World Health Organization (WHO) recommendations. Material and Methods: The study comprised 373 employees of randomly selected institutions. A short version of International Physical Activity Questionnaire (IPAQ) was applied. The correlation between the mean values of duration, days, MET-min/week of efforts, gender, and type of work was analyzed using the Tukey's honest significant difference (HSD) test, while the correlation between the level of physical activity and the socio-demographic characteristics was assessed with the $\mathrm{Chi}^{2}$ test. The strength of the relationship between socio-demographic characteristics and fulfilment of WHO standards was expressed by the odds ratio (OR) and 95\% confidence interval (95\% CI). The significance level was $p=0.05$. Results: High levels of physical activity were declared by $41.8 \%$ of the manual workers, $14.7 \%$ of the administration staff, and $7.3 \%$ of the technicians; $19 \%, 31.5 \%$ and $54.5 \%$, respectively, reported low levels of physical activity. Factors determining the fulfilment of the WHO recommendations include: the nature of work $(\mathrm{p}=0.003)$, education $(p=0.004)$, and income $(p=0.003)$. The risk of being inactive nearly doubles in the case of administration staff $(31.5 \%)$ and increases more than 4 times in the case of technicians $(54.5 \%)$. Respondents with secondary school education (31.6\%) are exposed to a 3-fold higher risk of inactivity, while in respondents with higher education (37.2\%), the level of the risk is 4-fold higher. Compared to those in the highest income group (23.4\%), people who earn less (34.1\%) are inactive almost twice as often. Conclusions: Urgent intervention is necessary in all studied groups: increased energy expenditure for recreation and locomotion, educational offers of employers to promote healthy lifestyle, management of leisure time budget, and strategies for changing behavior.
\end{abstract}

Key words:

Prevention, Physical activity, Administrative, Technical, Manual workers

\section{INTRODUCTION}

In today's offices and businesses, employees' body movements and physical effort has been almost entirely eliminated, while the operations that continue to be performed by the workers manually are repetitive and monotonous. The elements of movement put uneven strain on particular systems and parts of the body. It is believed that this problem affects in particular people working intellectually

Research was funded by the University of Physical Education and the Ministry of Science and Higher Education (grant DS-86; project leader: Professor Antoni K. Gajewski, Ph.D.) as well as with a grant from the Rector's Fund of the Warsaw School of Economics. Project leader: Elżbieta Biernat, Ph.D.

Received: January 20, 2014. Accepted: August 18, 2014.

Corresponding author: E. Biernat, Warsaw School of Economics Collegium of World Economy, Department of Tourism, Al. Niepodleglości 162, 02-554 Warszawa, Poland (e-mail: elzbieta.biernat@sgh.waw.pl). 
or performing light jobs (in sitting position), and to a lesser extent, people performing physical jobs (standing or walking, lifting heavy objects, or doing everyday tasks manually). However, traditional manual labor has been disappearing. In the case of difficult or heavy jobs, people are replaced by machines or perform their tasks using modern tools and technology, which results in an almost complete elimination of physical effort and thereby gives rise to serious health and social problems [1,2].

In such circumstances, health promotion programs, including worksite fitness programs that increase physical activity at the worksite, have become increasingly popular [3]. They are a kind of compensation service to boost the fitness and vitality of a person, reduce the cost of one's treatment [4] and stimulate the improvement of efficiency at work [5]. Studies have demonstrated a positive correlation between worksite fitness programs and improvement of factors such as absenteeism [6], stress [7], and injuries at work [8]. They have also shown a positive correlation between worksite fitness programs and improvement of the company image [4], work culture, and employee morale [9]. Physically active people are generally healthier and work better [10].

Employers take a keen interest in such effects and more and more often offer these programs to their employees [5,11]. An important argument addresses the measurable economic benefits [12]. Scientists claim that USD 3.48 is returned per dollar invested in health promotion at the worksite owing to reduced treatment costs, and reimbursement of USD 5.82 (per dollar invested) owing to lower absenteeism [13]. Researchers also emphasize that there is on average slightly more than a $25 \%$ reduction of the costs of sick leave, health care, damages, and disability [14]. The cost-effectiveness of implementing obesity prevention programs, which could translate into a lower incidence of disease, improved quality of life and longer lifespan, ranges from USD 1.44 to USD 4.16 (per pound of weight loss) [15].
In Poland, the total expenditure in health care (including public and private spending as well as investments) amounted to PLN 98.8 billion in 2010, which made up 7\% of Poland's Gross Domestic Product (GDP) [16]. It should be noted that rising health care costs will be particularly severe for the Polish society due to the forecasted declines in the number of people at working age, whose work will have to cover the growing costs of the system. Moreover, Poland is still a developing country that requires further investment in all elements of the economic and social system in order to maintain high economic growth and international competitiveness.

The aforementioned issues are an important reason for studying the duration and intensity of effort, depending on a person's profession and position. Therefore, the aim of the present research is to evaluate one of the positive indicators of health, i.e., levels of physical activity, with a standardized assessment tool, the International Physical Activity Questionnaire (IPAQ). The study included administration staff, technicians, and manual workers in Warszawa public institutions. Duration and frequency of all efforts (moderate and vigorous as well as walking) were analyzed: at the worksite, in and around the house, while travelling, and during leisure time. Factors affecting the likelihood of making effort, including the health recommendations of the World Health Organization (WHO), and factors increasing the risk of inactivity were studied. It is thought that the identification of the characteristics of a specific group may lead to better knowledge of its behavior and, consequently, organizing effective health promotion and intervention activities.

\section{MATERIAL AND METHODS}

The study involved 373 administrative, technical and manual workers (116 men, 257 women) of randomly selected public institutions in Warszawa (Table 1).

The selection consisted of 2 stages. The 1st stage was to randomly select 4-6 public institutions from among: 
Table 1. Characteristics of administration staff, technicians, and manual workers in Warszawa public institutions

\begin{tabular}{|c|c|c|c|c|c|c|}
\hline \multirow[b]{2}{*}{ Characteristic } & \multicolumn{2}{|c|}{ Administration staff } & \multicolumn{2}{|c|}{ Manual workers } & \multicolumn{2}{|c|}{ Technicians } \\
\hline & $\begin{array}{c}\text { men } \\
(\mathrm{N}=42)\end{array}$ & $\begin{array}{c}\text { women } \\
(\mathrm{N}=196)\end{array}$ & $\begin{array}{c}\text { men } \\
(\mathrm{N}=52)\end{array}$ & $\begin{array}{c}\text { women } \\
(\mathrm{N}=27)\end{array}$ & $\begin{array}{c}\text { men } \\
(\mathrm{N}=22)\end{array}$ & $\begin{array}{c}\text { women } \\
(\mathrm{N}=34)\end{array}$ \\
\hline \multicolumn{7}{|l|}{ Body mass index* $[\mathrm{n}(\%)]$} \\
\hline underweight $(<18.5)$ & $1(2.4)$ & $23(12.0)$ & - & $4(14.8)$ & - & $3(8.8)$ \\
\hline norm $(18.5-24.9)$ & $18(43.9)$ & $101(52.6)$ & $20(38.5)$ & $8(29.6)$ & $10(45.5)$ & $16(47.1)$ \\
\hline overweight (25.0-29.9) & $16(39.0)$ & $53(27.6)$ & $26(50.0)$ & $8(29.6)$ & $11(50.0)$ & $11(32.4)$ \\
\hline obesity (30.0-39.9) & $6(14.6)$ & $15(7.8)$ & $6(11.5)$ & $7(25.9)$ & $1(4.5)$ & $4(11.8)$ \\
\hline \multicolumn{7}{|l|}{ Marital status* [n (\%)] } \\
\hline in a relationship & $19(45.2)$ & $116(60.7)$ & $39(75.0)$ & $20(74.1)$ & $17(77.3)$ & $24(70.6)$ \\
\hline single (unmarried, divorced, widowed) & $23(54.8)$ & $75(39.3)$ & $13(25.0)$ & $7(25.9)$ & $5(22.7)$ & $10(29.4)$ \\
\hline \multicolumn{7}{|l|}{ Education $[\mathrm{n}(\%)]$} \\
\hline higher & $23(54.8)$ & $82(41.8)$ & - & - & $5(22.7)$ & $11(32.4)$ \\
\hline secondary & $19(45.2)$ & $111(56.6)$ & $43(82.7)$ & $16(59.3)$ & $17(77.3)$ & $23(67.6)$ \\
\hline vocational/primary & - & $3(1.5)$ & $9(17.3)$ & $11(40.7)$ & - & - \\
\hline \multicolumn{7}{|l|}{ Gross income per person in a family* $[\mathrm{n}(\%)]$} \\
\hline$>1300$ PLN & $10(24.4)$ & $57(30.3)$ & $35(72.9)$ & $18(72.0)$ & $6(28.6)$ & $12(36.4)$ \\
\hline 1300-2 100 PLN & $16(39.0)$ & $80(42.6)$ & $11(22.9)$ & $6(24.0)$ & $13(61.9)$ & $14(42.4)$ \\
\hline$>2100$ PLN & $15(36.6)$ & $51(27.1)$ & $2(4.2)$ & $1(4.0)$ & $2(9.5)$ & $7(21.2)$ \\
\hline Average age (years) $(\mathrm{M} \pm \mathrm{SD})$ & $40.7 \pm 13.2$ & $45.1 \pm 11.1$ & $47.9 \pm 12.9$ & $51.3 \pm 9.6$ & $48.5 \pm 10.0$ & $49.1 \pm 9.0$ \\
\hline
\end{tabular}

* Number of individuals given in Table 1 is lower than the number of respondents because some of them refused to answer the questions.

- universities - the University of Warsaw, the University of Physical Education, the Warsaw School of Economics, the Warsaw University of Life Sciences;

- hospitals - "Wolski," "Szaserów," Independent Complex of Public Health Care Clinics for Higher Education Schools in Warsaw (Samodzielny Zespół Publicznych Zakładów Opieki Zdrowotnej dla Szkół Wyższych w Warszawie) in Mochnackiego Street, Waryńskiego Street and Krakowskie Przedmieście Street;

- research institutes - Institute of Plasma Physics, Institute of Hygiene, Food and Nutrition, Institute of Meteorology and Water Management, Institute of Construction Technology;

- theatres - Syrena Theatre, Kwadrat Theatre, Aleksander Zelwerowicz State Theatre Academy, 6 film sets.
The 2nd stage consisted of selecting a specified number of people at each institution. At institutions employing up to 35 workers, the research included all of them. At institutions with more than 35 employees, $30 \%$ of the group was randomly chosen. Slightly different procedures were used for the film sets, where the interviews were carried out among all the employees present at work that day.

The study was conducted in the form of a questionnaire. Direct interviews were performed by trained and supervised interviewers and in accordance with a specific plan. The percentage of refusals to be interviewed was within the range of $3-5 \%$.

In order to examine the level of physical activity, the researchers applied a short version of the IPAQ. This allowed them to collect information about the frequency 
and duration of any physical effort (moderate and vigorous as well as walking) undertaken by the respondents in the previous week. On the basis of the values (expressed in MET-min/week) and after the standard calculations [17], physical activity levels (high, moderate, and low) were evaluated.

When assessing the level of physical activity, respondents who were sick, stayed in a hospital, underwent rehabilitation, had days off, etc., in the 7 days preceding the questionnaire were excluded from the analysis.

In accordance with the rules adopted by the authors of the IPAQ, the study was conducted only in March and November (2009). Periods connected with holidays (if they happened to be in this period) were excluded from the study since, at that time, there was an increased physical activity associated with holiday activities like visiting cemeteries, family gatherings, etc.

The interviewers also collected the information on gender, education, age, marital status, height and body mass, and income of the subjects.

Since the distributions of all variables did not differ considerably from normal, the relationship between the mean values of duration, days and MET-min/week of undertaken efforts and gender and type of work was analyzed using the ANOVA analysis. The comparisons of particular pairs of averages were conducted post hoc using the most reliable test, i.e., the Tukey's test. The relationship between the level of physical activity and socio-demographic characteristics (gender, age, body mass index (BMI), marital status, education, nature of work, income) was evaluated using the $\mathrm{Chi}^{2}$ test. Strength of the relationship between socio-demographic characteristics and conformity to the WHO health-related standards was expressed by the odds ratio (OR), which was determined with a $95 \%$ confidence interval. Log-linear analysis was applied to eliminate the relationship between the independent variables describing the level of physical activity. In all analyses, the level of significance was $p=0.05$. Calculations were performed using the statistics software package Statistica 10.

\section{RESULTS}

Vigorous physical effort that led to highly increased breathing and very fast heart rate was reported by $33.4 \%$ of all the respondents. This group included $54.8 \%$ of men and $28.5 \%$ of women employed in administrative positions; $43.1 \%$ of men and $40.7 \%$ of women employed in physical positions; and $23.8 \%$ of men and $20.6 \%$ of women employed in the technical positions. This type of effort was reported by manual workers $(42.3 \%)$ more often than by technical workers (21.8\%; Table 2) (Chi test; $\mathrm{p}<0.05)$. The average duration of vigorous effort in the group of manual workers was relatively higher $(48 \pm 81.2 \mathrm{~min} /$ day $)$ than in the group of technicians $(8.73 \pm 23.9 \mathrm{~min} /$ day; Tukey's HSD test; $p=0.002)$ and administration staff $(16.8 \pm 40.4 \mathrm{~min} /$ day; Tukey's HSD test; $p=0.003)$. Among the whole group, vigorous effort was made on average 2.7 \pm 1.9 times per week. Men reported it $2.4 \pm 1.7$ times per week; women reported it $2.9 \pm 2.1$ times per week. Significant differences were not found either in relation to the nature of work or in relation to the gender of the participant.

Weekly energy expenditure on vigorous effort, as calculated from the duration (during the day) and frequency (weekly), was 494.3 \pm 1407 MET-min/week $(754.1 \pm 1814$ for men and 378.1 \pm 1167 MET-min/week for women). At the same time, there were no significant differences between men and women in any of the analyzed groups. However, it was shown that the mean value of MET-min/ week of vigorous effort in the group of manual workers (Tukey's HSD test; $p=0.000$ ) was relatively higher than among the administration and technical staff (Table 2).

A total of $67.4 \%$ of the participants reported moderate effort that led to a slightly accelerated heart rate and slightly increased breathing. This included $61.9 \%$ of men and $68.4 \%$ of women employed in administrative 
Table 2. Average frequency, duration and weekly energy expenditure on physical effort undertaken by administration staff, technicians, and manual workers employed in Warszawa public institutions

\begin{tabular}{|c|c|c|c|}
\hline \multirow{2}{*}{ Physical effort } & \multicolumn{3}{|c|}{$\begin{array}{l}\text { Workers } \\
(\mathrm{M} \pm \mathrm{SD})\end{array}$} \\
\hline & $\begin{array}{l}\text { administrative } \\
(\mathrm{N}=238)\end{array}$ & $\begin{array}{c}\text { manual } \\
(\mathrm{N}=79)\end{array}$ & $\begin{array}{l}\text { technical } \\
(\mathrm{N}=56)\end{array}$ \\
\hline \multicolumn{4}{|l|}{ Vigorous effort } \\
\hline frequency (day/week) & $0.84 \pm 1.65$ & $1.27 \pm 1.95$ & $0.58 \pm 1.41$ \\
\hline duration (min/day) & $16.80 \pm 40.40$ & $48.00 \pm 81.20^{*}$ & $8.73 \pm 23.90$ \\
\hline weekly energy expenditure (MET-min/week) & $295.00 \pm 699.00$ & $1346.00 \pm 2631.00^{*}$ & $133.80 \pm 303.30$ \\
\hline \multicolumn{4}{|l|}{ Moderate effort } \\
\hline frequency (day/week) & $2.20 \pm 2.30^{\#}$ & $2.50 \pm 2.30^{*}$ & $1.40 \pm 1.90$ \\
\hline duration (min/day) & $53.00 \pm 73.00$ & $111.90 \pm 135.40^{*}$ & $39.00 \pm 56.80$ \\
\hline weekly energy expenditure (MET-min/week) & $648.00 \pm 1109$ & $1717.00 \pm 2878.00^{*}$ & $496.00 \pm 1084.00$ \\
\hline \multicolumn{4}{|l|}{ Walking } \\
\hline frequency (day/week) & $4.90 \pm 2.30^{\#}$ & $5.40 \pm 2.50$ & $3.50 \pm 2.60$ \\
\hline duration (min/day) & $42.20 \pm 42.20$ & $55.40 \pm 68.70$ & $33.70 \pm 33.60$ \\
\hline weekly energy expenditure (MET-min/week) & $733.38 \pm 790.70$ & $1182.80 \pm 604.60^{*}$ & $478.50 \pm 542.90$ \\
\hline
\end{tabular}

$\mathrm{M}$ - mean; SD - standard deviation.

Significantly different $(\mathrm{p}<0.05):$ * manual workers vs. technical and administrative staff; \# administrative vs. technical staff.

positions, $66.7 \%$ of men and $47.1 \%$ of women employed as technicians and $66.7 \%$ of men and $96.3 \%$ of women working manually. In general, the respondents undertook moderate effort $3.3 \pm 2$ times per week. There were no significant differences between men $(2.9 \pm 1.8)$ and women $(3.4 \pm 2)$ in this aspect. However, it was found that manual workers $(76.9 \%)$ reported this type of effort more often (Chi ${ }^{2}$ test; $\left.\mathrm{p}<0.05\right)$ than technicians $(54.5 \%)$. In addition, in comparison to the administration and technical staff, manual workers performed moderate effort more frequently (Tukey's HSD test; $p=0.014$ ) and longer (Tukey's HSD test; $\mathrm{p}=0.000$; Table 2).

Weekly energy expenditure at moderate effort was 852.5 \pm 1704 MET-min/week: 1113 \pm 2441 MET-min/week for men and $736.1 \pm 1229$ MET-min/week for women. As with vigorous effort, no significant differences were found between men and women in this respect in any of the analyzed groups. It was observed, though, that the mean value of MET-min/week of moderate efforts $(1717 \pm 2878)$ in the group of manual workers was relatively higher (Tukey's HSD test; $p=0.000)$ than among the administration staff $(648 \pm 1109)$ and technicians $(496 \pm 1084)$.

As many as $89.9 \%$ of the participants $(88.6 \%$ of men and $90.6 \%$ of women) declared that they walked without a break for at least 10 minutes. People working in the administration $(92.8 \%)$ reported walking significantly more often $\left(\mathrm{Chi}^{2}\right.$ test; $\left.\mathrm{p}<0.05\right)$ than those employed as technicians $(78.2 \%)$. This was similar in regard to the number of days of walking (Tukey's HSD test; $p=0.000$ ), as the administration staff walked more $(4.9 \pm 2.3$ days per week) than technicians $(3.5 \pm 2.6)$. Among manual workers, the percentage of the walkers was $89.7 \%$. This did not differ significantly from the other groups; however, the representatives of this group walked more often $(5.4 \pm 2.5$ times per week) than did technicians (Tukey's HSD test; $p=0.000)$. The average number of days of walking per week in the whole group was $5.4 \pm 1.9(5.6 \pm 1.9$ for men and $5.3 \pm 1.9$ for women). As with vigorous and moderate 
effort, no significant differences in the number of reported days of walking were found between men and women.

Weekly energy expenditure for walking was 791.1土 1016.3 MET-min/week (931.9 \pm 1369.8 MET-min/week for men and $728.14 \pm 805.3$ for women). There were no significant differences between men and women in any of the analysed groups. However, it was noted that the mean value of MET-min/week of walking in the group of manual workers was relatively higher than among the administration staff (Tukey's HSD test; $p=0.001$ ) and technicians (Tukey's HSD test; $p=0.000$ ).

Average duration of sitting for the respondents was $465.1 \pm 151.5 \mathrm{~min} /$ day. Administration staff spent sitting on average $488.5 \pm 130.7 \mathrm{~min} /$ day; manual workers $408.2 \pm 190.8 \mathrm{~min} /$ day; technicians $445.1 \pm 150.4 \mathrm{~min} /$ day. There were significant differences in the duration of sitting depending on gender (Tukey's HSD test; $p=0.018$ ) and the nature of work (Tukey's HSD test; $p=0.000$ ). Namely, women working manually spent relatively less time sitting (365.6 $\pm 209.3 \mathrm{~min} /$ day; Tukey's HSD test; $\mathrm{p}=0.000$ ) than women working in administration $(494.3 \pm 130.1 \mathrm{~min} /$ day) and technical units $(474.7 \pm 133.2 \mathrm{~min} /$ day; Tukey's HSD test; $p=0.046)$. Among men, significant differences (Tukey's HSD test; $p=0.046$ ) were found between the administrative staff $(461.4 \pm 131.5 \mathrm{~min} /$ day $)$ and technicians (397.1 $\pm 130.7 \mathrm{~min} /$ day)

After calculating total energy expenditure (adding up the values of MET-min/week of all the types of effort), respondents were classified according to their levels of physical activity. In total, $20.3 \%$ of the respondents $(22.6 \%$ of men and $17.9 \%$ of women) had high levels of physical activity, $49 \%$ (50.4\% of men and $47.5 \%$ of women) had moderate levels of physical activity, and $30.8 \%$ (27.0\% of men and $34.6 \%$ of women) had low levels of physical activity. Manual workers (41.8\%) were more likely to achieve a high level of physical activity $\left(\mathrm{Chi}^{2}\right.$ test; $\left.\mathrm{p}<0.05\right)$ than the others (administration staff $-14.7 \%$, technicians $-7.3 \%$; Figure 1). Moderate level of physical activity was noted

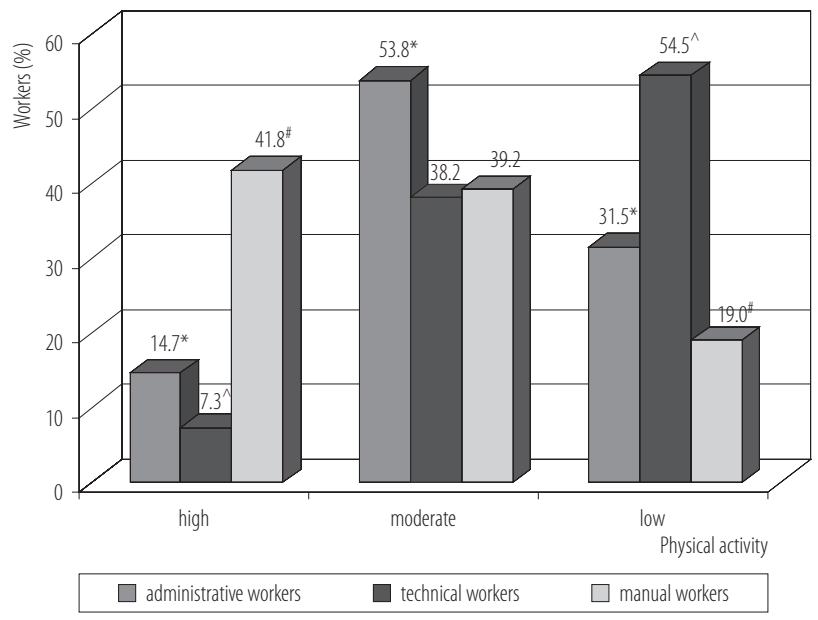

Significantly different $(\mathrm{p}<0.05):{ }^{*}$ administrative workers vs. manual and technical workers; $\wedge$ technical workers vs. manual and administrative workers; ${ }^{\#}$ manual workers vs. technical and administrative workers.

Fig. 1. Levels of physical activity among administrative, technical, and manual workers in Warszawa public institutions

mainly in administration staff (53.8\%); unlike them, technicians $(38.2 \%)$ and manual workers $(39.2 \%)$ achieved it relatively less frequently $\left(\mathrm{Chi}^{2}\right.$ test; $\left.\mathrm{p}<0.05\right)$. Furthermore, technical workers $(54.5 \%)$ were characterized by low levels of physical activity $\left(\mathrm{Chi}^{2}\right.$ test; $\left.\mathrm{p}<0.05\right)$ more often than administrative (31.5\%) and physical workers (19\%).

Analysis by gender showed that in the case of administrative and manual workers there were no significant differences between men and women in the classification of the different levels of physical activity. However, among women employed in technical positions (67.6\%) low levels of physical activity were reported relatively more often $\left(\mathrm{Chi}^{2}\right.$ test; $\mathrm{p}<0.05)$ than among men in that group $(38.1 \%)$. Men more often reached the level of moderate physical activity (57.1\% and $23.5 \%$, respectively).

Taking the WHO recommendations into account, participants were divided into those who met the guidelines (active group) and those who did not (inactive group). The 1st group included people with a low level of physical activity, the latter group comprised the others (with high and moderate levels; Table 3). 
Table 3. Factors determining the fulfilling of World Health Organization (WHO) recommendations by Warszawa administration staff, technicians, and manual workers $(\mathrm{N}=373)$ and $\mathrm{OR}$ as well as 95\% CI established for fulfilling WHO recommendations

\begin{tabular}{|c|c|c|c|c|c|}
\hline Factor & $\begin{array}{c}\text { Unfulfilled WHO } \\
\text { recommendations } \\
{[\mathrm{n}(\%)]}\end{array}$ & $\begin{array}{c}\text { Fulfilled WHO } \\
\text { recommendations } \\
{[\mathrm{n}(\%)]}\end{array}$ & $\mathrm{p}$ & OR & $95 \% \mathrm{CI}$ \\
\hline \multicolumn{6}{|l|}{ Gender } \\
\hline men & $31(27.0)$ & $84(73.0)$ & n.s. & 1.00 & - \\
\hline women & $89(34.6)$ & $168(65.4)$ & & 0.70 & $0.43-1.13$ \\
\hline \multicolumn{6}{|l|}{ Age (years) } \\
\hline $20-29$ & $19(38.8)$ & $30(61.2)$ & n.s. & 1.00 & - \\
\hline $30-39$ & $16(24.6)$ & $49(75.4)$ & & 1.94 & $0.87-4.34$ \\
\hline $40-49$ & $31(35.2)$ & $57(64.8)$ & & 1.16 & $0.57-2.40$ \\
\hline $50-59$ & $43(30.5)$ & 98 (69.5) & & 1.44 & $0.73-2.84$ \\
\hline $60-69$ & $11(37.9)$ & $18(62.1)$ & & 1.04 & $0.40-2.67$ \\
\hline \multicolumn{6}{|l|}{ Body mass index } \\
\hline underweight & $10(32.3)$ & $21(67.7)$ & n.s. & 1.07 & $0.47-2.43$ \\
\hline norm & $55(31.8)$ & $108(62.4)$ & & 1.00 & - \\
\hline overweight & $43(34.4)$ & $82(65.6)$ & & 1.00 & $0.59-1.59$ \\
\hline obesity & $9(23.7)$ & $29(76.3)$ & & 1.64 & $0.73-3.71$ \\
\hline \multicolumn{6}{|l|}{ Marital status } \\
\hline in a relationship & 78 (33.2) & $157(66.8)$ & n.s. & 1.00 & - \\
\hline single & $41(30.8)$ & $92(69.2)$ & & 1.11 & $0.71-1.76$ \\
\hline \multicolumn{6}{|l|}{ Education } \\
\hline higher & $45(37.2)$ & $76(62.8)$ & 0.004 & 0.25 & $0.07-0.90$ \\
\hline secondary & $72(31.6)$ & $156(68.4)$ & & 0.33 & $0.09-1.13$ \\
\hline vocational/primary & $3(13.0)^{*}$ & $20(87.0)$ & & 1.00 & - \\
\hline \multicolumn{6}{|l|}{ Worker } \\
\hline administrative & $75(31.5)^{*}$ & $163(68.5)$ & 0.003 & 0.51 & $0.27-0.95$ \\
\hline technical & $30(54.5)$ & $25(45.5)$ & & 0.23 & $0.11-0.51$ \\
\hline manual & $15(19.0)^{*}$ & $64(81.0)$ & & 1.00 & - \\
\hline \multicolumn{6}{|c|}{ Gross income per person in a family (PLN) $)^{\#}$} \\
\hline$<1300$ (EUR 312) & $47(34.1)$ & $91(65.9)$ & 0.003 & 0.59 & $0.31-1.11$ \\
\hline 1300-2 100 (EUR 312-504) & $47(34.1)$ & $93(66.4)$ & & 0.60 & $0.32-1.14$ \\
\hline 2100 (> EUR 504) & $18(23.4)$ & $59(76.6)$ & & 1.00 & - \\
\hline
\end{tabular}

OR - odds ratio (was computed with reference to the people unfulfilling WHO recommendations); CI - confidence interval.

\# Due to possible data deficiencies in income, the number of respondents may vary between individual variables.

* Significant differences $(\mathrm{p}<0.05)$ between the respondents fulfilling and unfulfilling WHO recommendations.

n.s. - not significant. 
Based on analyses of partial and marginal associations, it was found that among the considered variables only the nature of work, education and income were factors significantly affecting the fulfillment of the WHO recommendations. Odds ratios calculated for the analyzed variables indicated that the risk of being inactive increased almost twice $(\mathrm{OR}=0.51,95 \% \mathrm{CI}: 0.27-0.95)$ for administration workers $(31.5 \%)$ and more than 4 times $(\mathrm{OR}=0.23,95 \% \mathrm{CI}$ : $0.11-0.51)$ for technical workers $(54.5 \%)$. A similar risk of being inactive was also found in the least educated people, 3 times higher risk $(\mathrm{OR}=0.25,95 \% \mathrm{CI}$ : $0.07-0.90)$ for people with secondary school education $-31.6 \%$ and 4 times higher risk $(\mathrm{OR}=0.33,95 \% \mathrm{CI}: 0.09-1.13)$ in the case of respondents with higher (tertiary) education - 37.2\%. It was also observed that in comparison to those with the highest income $(23.4 \%)$, the lowest income group ( $\leq 2100$ PLN, $34.1 \%$ ) were almost twice more likely to be inactive and did not meet the WHO recommendations (13002100 PLN, OR $=0.59,95 \%$ CI: 0.31-1.11; < 1300 PLN, $\mathrm{OR}=0.60,95 \%$ CI: 0.32-1.14). Regarding the individual categories of gender, BMI and marital status, the proportions of active and inactive people were not significantly different.

\section{DISCUSSION}

Prevalent risk factors, morbidity, intensified aging processes, and increased spending on increasingly advanced therapies are causing an inevitable rise in health care costs [16]. Governments of industrialized countries (including Poland) are concerned about this phenomenon and are striving to maintain an appropriate state of their citizens' health. A growing number of active Poles, especially youths and working-age people, is one of the expected effects of the National Health Program. This program assumes that "by 2015, at least $60 \%$ of children and adolescents and $35 \%$ of adults will have involved in various forms of physical activity of a certain intensity and frequency in leisure time" [18]. Nevertheless, recent studies by NATPOL [16] have shown that only $32 \%$ of
Poles undertook physical activity every day or 4-6 days a week. It is "only $32 \%$ " because the analyzed efforts were not only connected with leisure time, but also with travelling and working.

The debate on the health benefits of physical activity at work continues $[19,20]$. Researchers point to the opposite effects: in some cohorts, high occupational physical activity is shown to be associated with improved health [21], while in other cohorts, high occupational physical activity is shown to impair health [20,22-24]. On the one hand, a positive correlation between physical activity and reduced risk of complications of cardiovascular diseases, diabetes, hypertension and obesity, premature mortality has been proven $[25,26]$. On the other hand, we have to face the problem of the lack of studies or findings on the adverse impact of physical activity on health [21,22].

Some studies have shown that much physical effort at the worksite does not mean improving functional ability and motor skills [27]. High occupational physical activity may increase the risk of absenteeism (determinant of global health) $[23,24]$, whereas increasing levels of physical activity in leisure time may reduce this risk (counteract and modify many unfavorable factors) [28,29]. Regardless of previous findings, the evaluation of one of the positive indicators of health - levels of physical activity - among the representatives of the 3 occupational categories (administration staff, technicians, and manual workers) may be a valuable tool in planning preventative activities targeted at people of working age.

The collected material indicated that $90 \%$ of the participants claimed that they walked, $33 \%$ did vigorous effort, and $67 \%$ did moderate effort. Yet a high level of physical activity (assessed on the basis of all efforts taken at the worksite, in and around the house, and while commuting) was attained by only $42 \%$ of the manual workers, $15 \%$ of the administration staff, and $7 \%$ of the technicians. Low levels of physical activity were characteristic of as many 
as $55 \%$ of the technicians, $32 \%$ of the administration staff, and $19 \%$ of the manual workers.

This tendency agreed with the conclusions of the most comprehensive study of health of the Polish population in 2009 ("Stan zdrowia ludności Polski w 2009 r."), conducted by the Central Statistical Office (Główny Urząd Statystyczny - GUS) [30]. It found that up to 54\% of adult Poles (aged 15 years and older) did not do any activity, and only $13 \%$ of respondents did it regularly or fairly often. Meanwhile, the average Pole is happy to declare various activities (28.2\% - activities requiring high physical effort, $66.8 \%$ - moderate, $76.1 \%$ - walking) [30]. However, after summing up the duration and frequency of those efforts, it became clear that the level of physical activity of the respondents was not sufficient to remain healthy. This raises the suspicion that Poles (both generally and in this study) are not willing to admit that they lack physical activity. The best proof is that only by asking detailed questions (about the duration and frequency of the efforts) the researchers were able to classify the Warszawa employees into those who met $(30.8 \%)$ and did not meet $(69.2 \%)$ WHO recommendations. Meanwhile, in Sweden, the percentage of people meeting the health recommendations is as high as $63 \%$ [31]. What determines the level of physical activity - or rather their inactivity - among the Warszawa administration staff, technicians, and manual workers? Most reports have emphasized that the primary factor in changing a lifestyle is the place of residence [32] and awareness [33] (clearly connected with profession [34], income [35], and education [33]). The larger the city, the higher the activity. The higher the education, the greater the awareness of the need to care for one's health and controlling its state, do sports and other healthy activities [36].

Unfortunately, the present analysis showed that within the studied group, higher education did not guarantee the rational care for one's own body and health. It turned out that - in contrast to what Jones et al. claim [37] - greater knowledge does not result in the avoidance of adverse states and minimizing their adverse effects. The risk of being inactive was 3-fold higher among the people with secondary school education $(31.6 \%)$ and 4-fold higher among the people with higher education (37.2\%). Bergman et al. [31] report similar observations $(\mathrm{OR}=0.5,95 \% \mathrm{CI}$ : 0.3-0.9). It is not surprising that physical activity of people with higher education is low since they mostly work at computers (administration - 44.1\%; technicians - 28.6\%). They spend sitting usually over 8 hours daily. Almost $40 \%$ of the administration staff and nearly $50 \%$ of the technicians are overweight or obese. Furthermore, researchers suggest that obese people should replace sitting at a computer with walking while working with the computer. According to the calculations, 2-3 h a day of such exercise (at constant other components of energy balance) may result in weight loss of as much as $20-30 \mathrm{~kg}$ per year [38].

However, it is striking that the technical and administrative staff did not compensate for a sedentary lifestyle with physical activity in their leisure time. The strength of the relationship of the failure to meet the WHO health standards and the nature of work was shown with the odds ratio $(\mathrm{OR}=0.51,95 \% \mathrm{CI}: 0.27-0.95)$. The risk of being inactive is increasing. In comparison to the manual workers, it almost doubled in the case of administrative employees $(31.5 \%)$ and it was more than 4 times higher for technical workers $(54.5 \%)$.

It is self-evident that the people working manually (mainly with secondary education $-74.7 \%$; primary/vocational education $-25.3 \%$ ) were more physically active at work. However, even within this group, $19 \%$ of the people were physically inactive. This raises 2 assumptions. First of all, traditionally understood manual labor has been disappearing and the effort associated with it is currently taken over by machines and technology [39]. Secondly, constant and chronic fatigue at work may entail further consequences. For example, it may become a cause of reluctant participation in sports and recreational activities in leisure time [40,41]. According to Drygas et al. [42], 
such an attitude is presented by $11 \%$ of respondents. However, there is also evidence that working adults who engage in physically demanding work or men in blue-collar occupations are more active outside of the worksite [43]. Economic status of people is an important factor that enhances their active lifestyles [37]. However, it should be noted that the impact of increased affluence on the healthoriented behaviors is not clear. On the one hand, it may encourage greater spending on recreation and sports facilities [44]. On the other hand, it may become a factor reinforcing unhealthy habits: the tendency to excessive, irresponsible consumption, the abandonment of physical activities (e.g., doing household chores). In the studied group, there is a positive correlation with physical activity. The respondents in the highest income group (23.4\%) met the WHO recommendations relatively more often than the others. In comparison to them, people who earned less $(\leq 2100$ PLN, $34.1 \%)$ were inactive almost twice as often.

\section{CONCLUSIONS}

Taking everything into consideration, the results of the present study point to the need for urgent intervention among all of the surveyed subjects (especially technical and administrative employees). Increasing recreation and locomotion energy expenditure in that group of people can be beneficial. Although increasing physical activity at work is not easy, an educational offer for employers regarding healthy lifestyle, management of leisure time budget, and strategies of behavior changes will definitely improve the current state of affairs. However, further research on effort at work, at home, in leisure time, and while travelling is necessary. Due to the limited scope of our work, the present results should be regarded with caution.

\section{REFERENCES}

1. Slaski M, Cartwright S. Health, performance and emotional intelligence: An exploratory study of retail managers. Stress Health. 2002;18(2):63-8, http://dx.doi.org/10.1002/smi.926.
2. van den Berg TIJ, Alavinia SM, Bredt FJ, Lindeboom D, Elders LAM, Burdorf A. The influence of psychosocial factors at work and life style on health and work ability among professional workers. Int Arch Occup Environ Health. 2008;81(8):1029-36, http://dx.doi.org/10.1007/s004 20-007-0296-7.

3. Best Employers For Healthy Lifestyles. Proving the value of employer well-being programs: How award winners measure success. A National Business Group on HealthSM Awards Program; 2014 [cited 2014 Jan 15]. Available from: https:// www.businessgrouphealth.org/pub/46938E4C-782B-CB6E2763-70C7349882F1.

4. Chau J. Evidence module: Workplace physical activity and nutrition interventions. Physical Activity Nutrition and Obesity Research Group (PANORG), University of Sydney; 2009 [cited 2014 Jan 15]. Available from: http:/sydney. edu.au/medicine/public-health/panorg/pdfs/Evidence_module_Workplace.pdf.

5. O'Donnell MP. Financial incentives for workplace health promotion: What is equitable, what is sustainable, and what drives healthy behaviors? Am J Health Promot. 2012;26(5):4-7, http://dx.doi.org/10.4278/ajhp.26.5.iv.

6. Gebhardt DL, Crump CE. Employee fitness and wellness in the workplace. Am Psychol. 1990;45(2):262-72, http:// dx.doi.org/10.1037/0003-066X.45.2.262.

7. Jasnoski ML, Holmes DS, Solomon S, Aguiar C. Exercise, changes in aerobic capacity, and changes in self perceptions: An experimental investigation. J Res Pers. 1981;15(4): 460-6, http://dx.doi.org/10.1016/0092-6566(81)90042-8.

8. Conn VS, Hafdahl AR, Cooper PS, Brown LM, Lusk SL. Meta-analysis of workplace physical activity interventions. Am J Prev Med. 2009;37(4):330-9, http://dx.doi.org/10.1016/ j.amepre.2009.06.008.

9. Anspaugh DJ, Hunter S, Mosley J. The economic impact of corporate wellness programs: Past and future considerations. AAOHN J. 1995;43(4):203-10.

10. Troiano RP, Berrigan D, Dodd KW, Mâsse LC, Tilert T, McDowell M. Physical activity in the United States measured 
by accelerometer. Med Sci Sports Exerc. 2008;40(1):181-8, http://dx.doi.org/10.1249/mss.0b013e31815a51b3.

11. Rudman WJ, Steinhardt M. Fitness in the workplace: The effects of a corporate health and fitness program on work culture. Health Val. 1988;12:4-17.

12. Witters D, Agrawal S. Unhealthy U.S. workers' absenteeism costs $\$ 153$ billion. Well-Being [Internet]. October 2011 [cited 2014 Jan 15]. Available from: http://www.gallup.com/ poll/150026/unhealthy-workers-absenteeism-costs-153-billion.aspx.

13. Wellness White Paper. The health and economic implications of worksite wellness programs. Return on investment in worksite health promotion. American Institute of Preventive Medicine; 2010 [cited 2014 Jan 15]. Available from: http://www.healthylife.com/template.asp?pageID=75.

14. Chapman LS. Meta-evaluation of worksite health promotion economic return studies: 2005 update. Am J Health Promot. 2005;19(6):1-11.

15. Anderson LM, Quinn TA, Glanz K, Ramirez G, Kahwati LC, Johnson DB, et al. The effectiveness of worksite nutrition and physical activity interventions for controlling employee overweight and obesity: A systematic review. Am J Prev Med. 2009;37(4):340-57, http://dx.doi.org/10.1016/ j.amepre.2009.07.003.

16. [Analysis of socio-demographic changes and the influence of unbalanced diet, insufficient physical activity, bad habits, and other risk factors on the spread of and the cost generated by diabetes and cardiovascular diseases in Poland: The current state and predictions through 2030]. KPNG [cited 2014 Jan 15]. Available from: http://zdrowepokolenia.org/dat. Polish. 17. Biernat E, Stupnicki R, Gajewski AK. [International Physical Activity Questionnaire (IPAQ)]. Phys Edu Sport. 2007;51(1):47-54. Polish.

18. [National Health Programme for 2007-2015. Annex to Resolution No 90/2007 of the Council of Ministers of 15 May 2007]. Available from: http://www2.mz.gov.pl/wwwfiles/ma_struktura/docs/zal_urm_npz_90_15052007p.pdf. Polish.
19. Hu G, Jousilahti P, Borodulin K, Barengo NC, Lakka TA, Nissinen A, et al. Occupational, commuting and leisure-time physical activity in relation to coronary heart disease among middle-aged Finnish men and women. Atherosclerosis. 2007;194(2):490-7, http://dx.doi.org/10.1016/j.atherosclerosis.2006.08.051.

20. Kristal-Boneh E, Harari G, Melamed S, Froom P. Association of physical activity at work with mortality in Israeli industrial employees: The CORDIS study. J Occup Environ Med. 2000;42(2):127-35, http://dx.doi.org/10.1097/000437 64-200002000-00005.

21. Barengo NC, Hu G, Lakka TA, Pekkarinen H, Nissinen A, Tuomilehto J. Low physical activity as a predictor for total and cardiovascular disease mortality in middle-aged men and women in Finland. Eur Heart J. 2004;25:2204-11, http:// dx.doi.org/10.1016/j.ehj.2004.10.009.

22. Krause N, Brand RJ, Kaplan GA, Kauhanen J, Malla S, Tuomainen TP, et al. Occupational physical activity, energy expenditure and 11-year progression of carotid atherosclerosis. Scand J Work Environ Health. 2007;33(6):405-24, http:// dx.doi.org/10.5271/sjweh.1171.

23. Holtermann A, Mortensen OS, Burr H, Søgaard K, Gyntelberg F, Suadicani P. Physical demands at work, physical fitness, and 30-year ischaemic heart disease and all-cause mortality in the Copenhagen Male Study. Scand J Work Environ Health. 2010;36(6):357-65, http://dx.doi.org/10.5271/ sjweh.2913.

24. Huber M, Lechner M, Wunsch C. Workplace health promotion and labour market performance of employees. IZA Discussion Paper No. 8297; June 2014 [cited 2014 Jan 15]. Available from: http://ftp.iza.org/dp8297.pdf.

25. Healthy workplaces journey to excellence: The complete guide. Ontario: Workplace Safety \& Prevention Services; 2011.

26. Probert AW, Tremblay MS, Gorber CS. Desk potatoes: The importance of occupational physical activity on health. Can J Public Health. 2008;99(4):311-8.

27. Ruzic L, Heimer S, Misigoj-Durakovic M, Matkovic BR. Increased occupational physical activity does not improve 
physical fitness. Occup Environ Med. 2003;60:983-5, http:// dx.doi.org/10.1136/oem.60.12.983.

28. Van den Heuvel SG, Boshuizen HC, Hildebrandt VH, Blatter B, Ariäns G, Bongers PM. Effect of sporting activity on absenteeism in a working population. Br J Sports Med. 2005;39:e15, http://dx.doi.org/10.1136/bjsm.2004.013052.

29. Van Amelsvoort LGPM, Spigt MG, Swaen GMH, Kant I. Leisure time physical activity and sickness absenteeism; A prospective study. Occup Med (Lond). 2006;56(3):210-2, http://dx.doi.org/10.1093/occmed/kqj026.

30. [Health status of Polish people in 2009]. Warszawa: Central Statistical Office; 2011. Polish.

31. Bergman P, Grjibovski AM, Hagströmer M, Bauman A, Sjöström M. Adherence to physical activity recommendations and the influence of socio-demographic correlates: A population-based cross-sectional study. BMC Public Health. 2008;8:367, http://dx.doi.org/10.1186/1471-2458-8-367.

32. Bergier J, Kapka-Skrzypczak L, Biliński P, Paprzycki P, Wojtyła A. Physical activity of Polish adolescents and young adults according to IPAQ: A population-based study. Ann Agric Environ Med. 2012;19(1):109-15.

33. Pan SY, Cameron C, DesMeules M, Morrison H, Craig CL, Jiang XH. Individual, social, environmental, and physical environmental correlates with physical activity among Canadians: A cross-sectional study. BMC Public Health. 2009;9: 21, http://dx.doi.org/10.1186/1471-2458-9-21.

34. Dishman RK, Sallis JF. Determinants and interventions for physical activity and exercise. In: Bouchard C, editor. Physical activity, fitness. Champaign (IL): Human Kinetics; 1994. p. 214-38.

35. Ortiz-Hernández L, Ramos-Ibáñez N. Sociodemographic factors associated with physical activity in Mexican adults. Public Health Nutr. 2010;13(7):1131-8, http://dx.doi. org/10.1017/S1368980010000261.

36. Hawkins SA, Cockburn MG, Hamilton AS, Mack TM. An estimate of prevalence of physical activity in a large population-based cohort. Med Sci Sports. 2004;36(2):253-60.
37. Jones DA, Ainsworth BE, Croft JB, Macera CA, Lloyd EE, Yusuf HR. Moderate leisure-time physical activity: Who is meeting the public health recommendations? A national cross-sectional study. Arch Fam Med. 1998;7(3):285-9.

38. Levine JA, Miller JM. The energy expenditure of using a "walk-and-work" desk for office workers with obesity. $\mathrm{Br}$ J Sports Med. 2007;41:558-61, http://dx.doi.org/10.1136/ bjsm.2006.032755.

39. Rifkin J. The end of work: The decline of the global labor force and the dawn of the post-market era. New York: Jeremy P. Tarcher; 1995.

40. Salmon J, Owen N, Bauman A, Schmitz MK, Booth M. Leisure-time, occupational, and household physical activity among professional, skilled, and less-skilled workers and homemakers. Prev Med. 2000;30(3):191-9, http://dx.doi.org/ 10.1006/pmed.1999.0619.

41. Morbidity and mortality weekly report. Contribution of occupational physical activity toward meeting recommended physical activity guidelines - United States, 2007. May 27, 2011 [cited 2014 Jan 15];60(20):656-60. Available from: http://www.cdc.gov/mmwr/preview/mmwrhtml/ mm6020a4.htm.

42. Drygas W, Skiba A, Bielecki W, Puska P. Physical activity estimation among the inhabitants of 6 European countries: Project "filling the Reducing East-West Health Gap". Med Sport. 2001;5 Suppl 2:119-25.

43. Kruger J, Yore MM, Ainsworth BE, Macera CA. Is participation in occupational physical activity associated with lifestyle physical activity levels? J Occup Environ Med. 2006;48(11):1143-8, http://dx.doi.org/10.1097/01.jom.000024 5919.37147.79.

44. Hallal PC, Victora CG, Wells JCK, Lima RC. Physical inactivity: Prevalence and associated variables in Brazilian adults. Med Sci Sports Exerc. 2003;35(11):1894-900, http:// dx.doi.org/10.1249/01.MSS.0000093615.33774.0E.

This work is available in Open Access model and licensed under a Creative Commons Attribution-NonCommercial 3.0 Poland License - http://creativecommons.org/ licenses/by-nc/3.0/pl/deed.en. 